DOI https://doi.org/10.30525/978-9934-26-114-5-60

\title{
РОЗВИТОК «SOFT SKILLS» У ЗДОБУВАЧІВ ВИЩОÏ ОСВІТИ ПІД ЧАС ВИВЧЕННЯ НАВЧАЛЬНОЇ ДИСЦИПЛІНИ «ПРАВОВА СОЦІАЛІЗАЦІЯ ДІТЕЙ ТА МОЛОДІ»
}

\author{
Сизоненко I. Г \\ кандидат педагогічних наук, \\ доцент кафедри соиіальної роботи та інклюзивної освіти \\ Бердянський державний педагогічний університет \\ м. Бердянськ, Україна
}

Соціальний педагог - це фахівець, який володіє не лише спеціальними вузькопрофільними знаннями, професійними компетентностями, що лежать в основі його соціалізуівальної, соціальноправової діяльності з дітьми та молоддю. Сучасні запити суспільства та держави вимагають від спеціаліста соціальної сфери розвинених навичок самостійно соціалізуватися, швидко адаптуватися, бути мобільним, гнучким, постійно розвивати власний творчий потенціал, вчитися, працювати у команді, ефективно вирішувати соціально-правові ситуації та конфлікти. Сформовані особистісні («soft skills»), професійні навички («hard skills»), а також спеціалізовані знання, професійні компетентності, створюють основу для становлення та розвитку конкурентоспроможного фахівця.

«Soft skills» («м'які» навички) - це здібності, що пов'язані 3 поведінкою, міжособистісним спілкуванням, дозволяють бути успішними у професійній діяльності; складно вимірюються та формуються, проте важливі для довгострокового успіху. Такі навички мають різні варіації назв: personal skills (особистісні навички) interpersonal skills (навички міжособистісного спілкування), non-tehnikal skills (нетехнічні навички), essential skills (основні навички), transferable skills (передані навички) [3]. Для побудови успішної кар'єри, професійної реалізації, конкурентоспроможності у європейському освітньому просторі виокремлюють такі найважливіші «soft skills»: навички комунікації, командної роботи, творчі навички, навички публічного виступу, критичного мислення та адаптивності [1].

Вимоги щодо забезпечення якісного рівня сучасної вищої освіти вимагають переосмислення змісту освітнього процесу, зокрема, використання інноваційних методів навчання, новітніх інтерактивних практик з розвитку та вдосконалення «soft skills» здобувачів вищої 
освіти спеціальності «Соціальна робота. Соціальна педагогіка». Так, навчальна дисципліна «Правова соціалізація дітей та молоді» $є$ вибірковою компонентою освітньо-професійної програми «Соціальна робота та соціальна педагогіка» для здобувачів першого (бакалаврського) рівня вищої освіти. Метою іiі викладання $\epsilon$ розширення знань майбутніх соціальних педагогів 3 питань правової соціалізації дітей та молоді, формування уявлень про соціальнопедагогічні механізми правової соціалізації, розвиток навичок використання їх у практичній соціально-педагогічній діяльності.

Під час опанування навчальної дисципліни у студентів розвиваються такі «soft skills»: управління правовою інформацією, вираження власної думки та прийняття рішень, ведення переговорів, дотримання відповідальної поведінки.

М'які навички роботи 3 інформацією, які $\epsilon$ складовою управлінських, комунікативних, соціально-захисних компетентностей соціального педагога, полягають у самостійному здобутті інформації, критичному іiі осмисленні, оцінці, аналізу, виокремлення з великого обсягу головного, правильного формулювання запиту на iї пошук, структуруванні матеріалу, опрацюванні різних джерел інформації при розв'язанні соціально-правових проблем, роботі з дітьми та молоддю тощо. Одним із сучасних і необхідних методів роботи з інформацією $\epsilon$ фактчекінг (fact checking - перевірка фактів), що спрямований на виявлення достовірності відомостей, невідповідності між реальними фактами та фейками [2]. Студенти дізнаються де шукати і як використовувати джерела перевірки інформації, яка відповідальність може настати за поширення дезінформації. Критично осмислювати, оцінювати, аналізувати інформацію студентам допомагають методи розвитку критичного мислення, зокрема, метод «Шести капелюхів мислення», «Шість пар взуття способу дій» (Едвард де Боно), «Діаграма (коло) Вена», «Кубування», методи проектів та ін. Окрім цього, дієвими формами роботи 3 формування навичок роботи 3 інформацією є прес-конференції, судові слухання, дискусійні клуби, дебати.

«Soft skills» вираження власної думки та прийняття рішень складають основу комунікативних, організаційних компетентностей соціального педагога. Охоплюють вміння самостійно вести дискусію, використовуючи правові терміни, відстоювати власну думку, поважаючи думки інших, виступати перед аудиторією, відповідати на поставлені запитання, робити висновки. Також основу комунікаційної, а разом з цим і медіаційної, управлінської компетентності соціального педагога складають навички ведення переговорів, що полягають у 
формування здатності вербального та невербального обміну інформацією, вироблення техніки аргументації, стратегії, тактики налагодження діалогу, взаємодії, а також мають велику професійну вагу у соціально-правовій, захисній та медіаційній роботі соціального педагога. У цьому аспекті значущими $є$ методи «Світове кафе», «Дерево рішень» або «Калейдоскоп», що передбачають можливість висловитися кожному учаснику заняття 3 певного питання в умовах обмеженого часу, домовитися між собою та визначити чіткі позиції щодо заданої теми. Зокрема, виконання завдань, що мають обмеження часу, дедлайни, формують навички планувати, розподіляти власний час, контролювати хід виконання вправи. Використання на заняттях застосунків Kahoot, Wordwall, LearningApps, Baamboozle, Quizlet надають можливість регламентувати час для проходження завдань.

Необхідними особистісними та суспільними навичками є навички дотримання відповідальної поведінки, що регулюються не лише внутрішніми потребами особистості, суспільними моральними правилами, але й регламентуються законодавчими нормами держави. Такі навички $\epsilon$ складовими компонентами правової свідомості та правової поведінки, що лежать в основі правової соціалізації особистості. Розвиток «soft skills» відповідальної поведінки полягає у формуванні правової свідомості, правових установок, цінностей, мотивів діяльності, соціалізувальних навичок, здатності визначати власну активну правову позицію, свідомо дотримуватися правомірної поведінки, реалізовувати й захищати свої права, взаємодіяти 3 соціальним середовищем, виконувати професійні обов'язки. Для розвитку навичок управління власною поведінкою студентам можна запропонувати участь у дискусії «Правові наслідки моїх дій», вікторині «Відповідальність у законах», грі-конкурсі «Декларація наших прав», дебатах «Я серед людей ступінь свободи» тощо.

Розвиток «soft skills» у здобувачів вищої освіти процес безперервний і багато в чому залежить від бажання самих студентів розвиватися, навчатися та стати висококваліфікованим, конкурентоспроможними фахівцями. Впровадження в освітній процес інтерактивних, сучасних та цікавих методів, технік, форм роботи стане запорукою ефективного розвитку необхідних м'яких навичок майбутніх соціальних педагогів у роботі з дітьми та молоддю.

\section{Лiтература:}

1. Becton Loveles Teaching Soft Skills : The Complete Guide [Електронний pecypc] // Education corner. - Режим доступу : http://surl.li/zixf 
2. Cambridge Dictionary [Електронний ресурс] - Режим доступу : https://dictionary.cambridge.org

3. Soft Skills: Definitions and Examples [Електронний ресурс] // Indeed Career. - Режим доступу : http://surl.li/zixs

4. Пометун О. І. Сучасний урок. Інтерактивні технології навчання. / Пометун О. І., Пироженко Л. В. - [Електронний ресурс]. - Режим доступу : http://surl.li/zleg

DOI https://doi.org/10.30525/978-9934-26-114-5-61

\title{
ФРЕЙМОВЕ СТРУКТУРУВАННЯ НАВЧАЛЬНОГО МАТЕРІАЛУ НА УРОКАХ ІНОЗЕМНОї МОВИ
}

\author{
Соколова С. B. \\ кандидат педагогічних наук, \\ дочент кафедри іноземних мов \\ Криворізький національний університет \\ Костіна Л. С. \\ кандидат педагогічних наук, \\ старший викладач кафедри іноземних мов \\ Криворізький національний університет \\ м. Кривий Ріг, Дніпропетровска область, Украӥна
}

Сьогодні викладачі іноземної мови професійного спрямування ведуть активний пошук ефективних технологій, які здатні істотно підвищити інтенсивність освітнього процесу. У цьому контексті значно зросла увага до когнітивної візуалізації інформації, зокрема використання фрейма як когнітивної структури та розкриття можливостей використання фреймових технологій у навчанні іноземній мові.

Категорію «фрейм» введено в 1974 р. М. Мінським, відомим дослідником у галузі штучного інтелекту. Концепція фреймів формувалася в контексті Стенфордського проекту створення інтегрального робота. Фрейми означали стереотипні, еталонні сцени, добре відомі людині з життєвого досвіду або спеціальних знань, під які можна було підводити нові, близькі до них сцени, щоб у такий спосіб розпізнавати структуру нових сцен і ситуацій.

Подальшими дослідженнями теорії фреймів займалися такі американські вчені, як Ч. Філлмор, 3. Шенк та інші. Фрейм представляє собою форму, яка прийнята в сучасній лінгвістиці для спрощеного 